\title{
Contemporaneity is a war zone
}

\author{
Ricardo Barberena \\ Pontifícia Universidade Católica do Rio Grande do Sul. Porto Alegre, Rio Grande do Sul, Brazil.
}

$\mathrm{T}$ There was this one time, during a course lectured at DELFOS/PUCRS, when João Gilberto Noll stated: "Contemporaneity is a war zone". Theorizing on contemporary literature means running the risk of finishing a discussion amidst face-slapping. Virginia Woolf had already warned us about the perils of this sort of literature, for we stroll into a minefield in which "two critics at the table, at the same moment, will utter completely divergent opinions on the very same book" (WOOLF, 2007, p. 104). Unable to issue the traditional judgment of value in canonized works, literary criticism, devoid of coercion and consensus practices, ends up endeavoring the risky provisional status of its readings. No wonder critics may "inevitably end up slapping each other" (WOOLF, 2007, p. 104). In agreeing to navigate contemporary seas, we take on the risk of a constant ongoing-knowledge which not seldomly treads a collision and conflicting path, for the same book may be understood as both a long-lasting contribution to literature and a mere variety of pretentious mediocrity. Various questions begin to storm the flanks of the criticism host: When does contemporaneity start? What is the predominant aesthetic characteristic of contemporary Brazilian literature?

In order to attempt at a partial answer, one needs to ponder on an ethics of contemporaneity. According to Agamben, it is only possible to define as contemporary that who does not allow herself to be blinded by the lights of the century and manages to discern shades in them. When roaming this perverse obscurity, the contemporary passenger is the one who perceives the darkness of her time as concerning herself, ceaselessly interpreting it, for "contemporary is the one who receives head on the beam of darkness arising from her time" (AGAMBEN, 2009 , p. 60). Thinking in these terms, contemporaneity is no longer set aside under the synchronic arbitrariness orchestrated according to epistemological and discursive demands. That is: contemporaneity here begins after the second world war, whereas there it starts at the turn of the
21 st century, and yonder it begins after medievalism. Over this oscillating temporal promiscuity, contemporaneity turns into a shapeless substance fitting infinite steel boxes of a fictionalized power/lore in multiple plots of knowledge. However, if we start from a neurophysiology of contemporaneity, we shall not be concerned with temporal cuts and foundational period-assigning, but with the potential aiming-through-the-darkness of the margin, the remote, the subservient, the eccentric. That is why the contemporary ones "are rare" (AGAMBEN, 2009 , p. 59). Being contemporary is, above all, a "matter of courage" (AGAMBEN, 2009, p. 59), for it means being capable of keeping an eye on the dark side of an era while also perceiving in it a light that, directed to us, infinitely distances itself from us. Confronting this reading of contemporaneity as an ethos in relation to the traditional concept of time, already plentifully questioned due to its anarchical and obtuse character, a central problematization arises: Who am I a contemporary of? For Roland Barthes, in an incidental note, "contemporary is what is untimely" (apud AGAMBEN, 2009, p. 58). Contemporaneity would be a singular relationship with one's own time, adhering to it and at the same time distancing itself from it; more precisely, however, it is the relationship with the time adhering to it through dissociation and anachronism. From this fluidity on contemporary belonging, we do not need to track the writer's, the philosopher's, the artist's date of birth so that we may alchemically baptize him as a contemporary being. The "baptismal" mechanism migrates from a temporal space (historical) to an identity brokerage space. For Marc Augé, three guiding questions must be articulated: "What does it mean to be from your own time?, What does our time mean today?, Where are the articulation spots between our time and the artistic or literary creation?" (AUGÉ, 2012, p.45). Michel Leiris' thought is still worth remembering; he highlights that it is always hard to define and place the specific characters of the time one lives in. According to both 
thinkers, contemporaneity does not mean up-to-date. We must not fall into the trap of an innocent correlational equation in which there is a perfect correspondence between contemporaneous and up-to-date. It is exactly here that we claim the neurophysiological remark of vision as a possibility of identification of the contemporary condition. The major challenge is in the absence of paradigmatic time frames, for discussing contemporary literature is above all asking when is contemporaneous.

And what about contemporary Brazilian literature? Where does it stand? What is its face? Over events and classes, we are often questioned: And then, professor, what is the identity of contemporary Brazilian literature? Here we must elaborate some thought that is not ratified by comparison systems and by the so-called steadiness of contemporary poetics. When we find ourselves before such plural aesthetic projects, we perceive absolutely heterogenous quadrants that may vary from Elvira Vigna's mutilation-word to Almicar Bettega's breathing-word. Therefore, we may have to answer that contemporary Brazilian literature is constellatory. After all, a constellatory epistemology presents itself against the moment of Cartesian subjectivity, less concerned with owning the phenomenon than with liberating it into its own sensible self and preserving its uneven elements in all of their irreducible heterogeneity. The constellation refuses to attach to a metaphysical essence, openly articulating its components. As highlighted by Terry Eagleton, in his wonderful analysis of Walter Benjamin's work, the concept of constellation is perhaps one of the "most original modern attempts at breaking with traditional versions of totality, representing a resistance against the most paranoid forms of totalizing thought by thinkers who are opposed to every simple empirical celebration of the fragment" (EAGLETON, 1993, p. 240). The contemporary-constellatory Brazilian literature breaks up with traditional versions of totality, for the lethal continuum of history appears to be shaken by the splinters and shrapnel of an aesthetics in constant parallax: from intimism to realism, from local to urban, from fantastic to marginal. If we think of contemporary literature as a constellation sky, not simply characterized by a unitary trace, we may see an identification that may not be summarized in a few identity particularizations. We shall, then, exercise an incidental criticism open to what falls lightly, as a leaf, on the carpet of life; that light fold, stealthy, on the fabric of days; that which can hardly be perceived: "some sort of ground zero of the note, only what is necessary to allow for writing something" (BARTHES, 2004, p. 47).

According to Sergio Vaz, "sometimes a poem is the kiss that lands before the mouth does" (VAZ, 2012, p.95). Perhaps contemporary literature is that kiss that arrives before the mouth does. This mouth which is made to relinquish judgment and values. This mouth prevented from defining borders between high and low literature. This mouth forced to hold certainties. Anyway, researching contemporaneity means to venture through provisional and fleeting empathy. It means hesitating on speaking and not speaking. It means being kissed by a literary text even if one is not able to explain it.

\section{References}

AGAMBEN, Giorgio. O que é o contemporâneo? E outros ensaios. Chapecó: Argos, 2010.

AUGÉ, Marc. Para onde foi o futuro? Campinas: Papirus, 2012.

BARTHES, Roland. A preparação do romance. São Paulo: Martins Fontes, 2004. v. 1.

EAGLETON, Terry. A ideologia da estética. Rio de Janeiro: Jorge Zahar, 1993.

VAZ, Sergio. Literatura, pão e poesia. São Paulo: Global, 2012.

WOOLF, Virginia. O leitor comum. Rio de Janeiro: Graphia, 2007.

\section{Organizer}

(D) RICARDO BARBRRENA <ricardo.barberena@pucrs.br>

Pontifícia Universidade Católica do Rio Grande do Sul (PUCRS), Porto Alegre, Rio Grande do Sul, Brazil. 